\title{
Content and Uptake of Selected Microelements with Potato Tuber Yield Treated with Biostimulators
}

\author{
Iwona Mystkowska1* , Anna Rogóż-Matyszczak² \\ 1 Department of Agriculture, Pope John Paul II State School of Higher Education. Sidorska 95/97, 21-500 Biała \\ Podlaska, Poland \\ 2 Laboratory of Environmental Analyzes EKO-AGRO-TECH, Pope John Paul II State School of Higher Education \\ in Biala Podlaska, Sidorska 95/97, 21-500 Biała Podlaska, Poland \\ * Corresponding author's: e-mail: imystkowska@op.pl
}

\begin{abstract}
A field experiment was conducted in Międzyrzec Podlaski, (51 $59^{\circ} \mathrm{N}$ and 22 $47^{\prime} \mathrm{E}$ ), Poland in the period from 2015 to 2017. The experiment was a two-way random split-plot arrangement of plots with three replicates. The following factors were examined: three varieties of potato - Honorata, Jelly, Tajfun, and four variants of application of biostimulants (Kelpak SL, Titanit, GreenOk, BrunatneBio Złoto). The control object comprised potato plants sprayed with distilled water. Biostimulators were applied to potato plants three times (beginning of flowering, full flowering and after flowering of the plants). The aim of the study was to determine the effect of biostimulants on the content and uptake of zinc and copper with the yield of potato tubers. High amount of rainfall in 2017 contributed to an increase in the content of zinc and copper in potato tubers. The tubers of potatoes treated with BrunatneBio Złoto had the highest contenting uptake of $\mathrm{Zn}$ and $\mathrm{Cu}$ compared to the control plants. The content of microelements in the tubers was significantly dependent on the genotype. The highest concentrations of $\mathrm{Zn}$ and $\mathrm{Cu}$ were found in the Honorata tubers, and the largest uptake was observed in the Jelly variety.
\end{abstract}

Keywords: variant, Solanum tuberosum varieties, zinc, copper

\section{INTRODUCTION}

Edible potato (Solanum tuberosum L.) is one of the main crops, tubers of which are a valuable source of many essential minerals [Camire et al. 2009, Brown et al. 2011, Leszczyński 2012, Alamar et al. 2017]. The concentration of mineral components in tubers is influenced by genetic and environmental factors [Klikocka 2001, Gugała et al. 2011, Szewczuk 2009]. Many authors showed that the quantity of micro elements in tubers depended on the variety [Żołnowski 2013, Muhamud et al. 2015, Wierzbowska et al. 2016].

In the available literature, there are few papers on the effect of biostimulants on the content of minerals in potato tubers.

Biostimulants are most often applied foliarly, for preventive or interventional purposes. Their function consists in stimulating the growth of leaves, stems and roots of the plant, replenishing the shortage of ingredients during the growing season caused by various factors, including intensive plant growth, drought and agrotechnical errors [Maciejewski et al. 2008, Trawczyński 2014, Kołodziejczyk 2016]. They enable more efficient absorption of nutrients from the ground [Zarzecka and Gugała 2018, Van Oosten et al. 2017, Pszczółkowski and Sawicka 2018], and thus a better supply of nutrients to plants [Gawrońska and Przybysz 2011]. A biostimulator used while the plants are still healthy should change the metabolism in such a way that they become stronger and more resistant to a pathogen attack or drought [Czeczko and Mikos-Bielak 2004, Farouk 2015].

The aim of the study was to determine the effect of biostimulators on the content and uptake of zinc and copper with the yield of potato tubers. 


\section{MATERIAL AND METHODS}

A field experiment was carried out in Międzyrzec Podlaski, (51 $59^{\prime} \mathrm{N}$ and $\left.22^{\circ} 47^{\prime} \mathrm{E}\right)$, Lubelskie Voivodeship, Poland, from 2015 to 2017. The experiment was a two-way split-plot arrangement with three replicates. The plot area at harvest was $15.0 \mathrm{~m}^{2}$ accounted of five ridges, on a very good rye complex soil of class IVa. In the years of the experiment, had a variable content of organic matter and available macroelements (Table 1). In 2015 and 2016, soil pH was slightly acidic (5.60) whereas in 2017 it was neutral (6.35). The organic matter content ranged from 15.0 to $18.7 \mathrm{~g} \cdot \mathrm{kg}^{-1}$. The available phosphorus (P) content ranged from high to very high, available potassium $(\mathrm{K})$ content ranged from average to very high, and magnesium $(\mathrm{Mg})$ content was high.

The factors were as follows: factor I - three table potato cultivars: Honorata, Jelly and Tajfun; factor II - four variants of application of biostimulants: Kelpak SL (active substance - Ecklonia maxima algae extract), containing plant hormones: auxin - $11 \mathrm{mg} \cdot \mathrm{l}^{-1}$ and cytokinin $0.031 \mathrm{mg} \cdot \mathrm{l}^{-1}$; Titanit (active substance - titanium); GreenOk (active substance - humus substances $20 \mathrm{~g} \cdot 1^{-1}$ ); BrunatneBio Złoto (active substances - plant hormones: auxin $-0.06 \mathrm{mg} \cdot \mathrm{l}^{-1}$ and cytokinin $\left.-12 \mathrm{mg} \cdot \mathrm{l}^{-1}\right)$. The control object comprised potato plants sprayed with distilled water.

Winter wheat crops preceded the table potato in each study year. The same organic manuring and mineral fertilization were applied: $25.0 \mathrm{t} \cdot \mathrm{ha}^{-1}$ farmyard manure (autumn) as well as $100 \mathrm{~kg} \cdot \mathrm{ha}^{-1} \mathrm{~N}$ (spring), $44 \mathrm{~kg} \mathrm{P} / \mathrm{ha}$ and $125 \mathrm{~kg}$ $\mathrm{K} / \mathrm{ha}$ (autumn). The control of diseases and pests in accordance with the requirements of agricultural practice was the same for all treatments. The potato tubers were planted by hand in the third decade of April and harvested in early September at the stage of physiological maturity. The potato tuber samples (50 tubers) were collected from the plots during harvest and stored at $10-12{ }^{\circ} \mathrm{C}$.for chemical analysis.

\section{Chemical analysis methods}

The potato tuber contents of zinc and copper were determined by with SpectroBlue ICP OES spectrometer at the Regional Research Center for Environment, Agricultural and Innovative Technologies, Pope John II State School of Higher Education in Biała Podlaska, after tubers had been cut and dried.

\section{Meteorological conditions}

The weather conditions during the years of research were varied (see Table 2). The highest average air temperature was recorded in 2016 and amounted to $15.8^{\circ} \mathrm{C}$, it was higher than the long-term average by $0.8^{\circ} \mathrm{C}$, while this year was characterized by the lowest amount of precipitation $-200.9 \mathrm{~mm}$, lower by $134.5 \mathrm{~mm}$ from the long-term sum. The highest number of rainfall was recorded in the growing season of 2017 $325.4 \mathrm{~mm}$ and the lowest average air temperature $-14.6^{\circ} \mathrm{C}$. The growing season of 2015 proved to be an average air temperature of $15.2^{\circ} \mathrm{C}, 0.2^{\circ} \mathrm{C}$ higher than the long-term average and precipitation at $295.1 \mathrm{~mm}$ (Table 2).

\section{Statistical analysis}

The results of the study were analysed by ANOVA. The significance of sources of variation was checked with the Fisher-Snedecor test and the significance of differences between means was tested using the multiple comparison Tukey's test at the significance level of $\mathrm{P}=0.05$. The statistical calculations were performed in Microsoft Excel software using an own algorithm based on the mathematical model [Trętowski and Wójcik, 1991].

Table 1. The acidity of the soil and the content of available forms of soil potassium, phosphorus, magnesium and organic matter

\begin{tabular}{|c|c|c|c|c|c|}
\hline Years & $\begin{array}{c}\mathrm{pH} \\
\left(1 \mathrm{~mol} \mathrm{KCl} \mathrm{dm}{ }^{-3}\right)\end{array}$ & $\begin{array}{c}\text { Content of K } \\
\left(\mathrm{mg} \mathrm{kg}^{-1}\right)\end{array}$ & $\begin{array}{c}\text { Content of P } \\
\left(\mathrm{mg} \mathrm{kg}^{-1}\right)\end{array}$ & $\begin{array}{c}\text { Content of Mg } \\
\left(\mathrm{mg} \mathrm{kg}^{-1}\right)\end{array}$ & $\begin{array}{c}\text { Organic matter } \\
\left(\mathrm{g} \mathrm{kg}^{-1}\right)\end{array}$ \\
\hline 2012 & $5.60-$ slightly acidic & $\begin{array}{c}145.4 \\
(\text { very high) }\end{array}$ & $\begin{array}{c}65.6 \\
(\text { high })\end{array}$ & $\begin{array}{c}51.0 \\
(\text { high })\end{array}$ & 15.0 \\
\hline 2013 & $5.60-$ slightly acidic & $127.0($ high $)$ & $\begin{array}{c}74.4 \\
\text { (high) }\end{array}$ & $\begin{array}{c}52.0 \\
\text { (high) }\end{array}$ & 16.0 \\
\hline 2014 & $6.35-$ neutral & $\begin{array}{c}145.4 \\
\text { (medium) }\end{array}$ & $\begin{array}{c}114.0 \\
\text { (very high) }\end{array}$ & $\begin{array}{c}55.0 \\
\text { (high) }\end{array}$ & 18.7 \\
\hline
\end{tabular}


Table 2. Weather conditions during of potato vegetation (Zawady Meteorological Station, $\left(52^{\circ} 03^{\prime} \mathrm{N}\right.$ and $22^{\circ} 33^{\prime}$ E), Poland)

\begin{tabular}{|c|c|c|c|c|c|c|c|c|}
\hline \multirow{3}{*}{ Months } & \multicolumn{4}{|c|}{ Air temperature $\left({ }^{\circ} \mathrm{C}\right)$} & \multicolumn{4}{|c|}{ Rainfall (mm) } \\
\hline & \multirow{2}{*}{\begin{tabular}{|c|} 
multi-year mean \\
$1996-2010$
\end{tabular}} & \multicolumn{3}{|c|}{ monthly means } & \multirow{2}{*}{$\begin{array}{c}\text { multi-year mean } \\
1996-2010\end{array}$} & \multicolumn{3}{|c|}{ monthly sums } \\
\hline & & 2015 & 2016 & 2017 & & 2015 & 2016 & 2017 \\
\hline April & 8.0 & 8.2 & 9.1 & 6.9 & 33.6 & 30.0 & 28.7 & 59.6 \\
\hline May & 13.5 & 12.3 & 15.1 & 13.9 & 58.3 & 100.2 & 54.8 & 49.5 \\
\hline June & 17.0 & 16.5 & 18.4 & 17.8 & 59.6 & 43.3 & 36.9 & 57.9 \\
\hline July & 19.7 & 18.7 & 19.1 & 16.9 & 57.5 & 62.6 & 35.2 & 23.6 \\
\hline August & 18.5 & 21.0 & 18.0 & 18.4 & 59.9 & 11.9 & 31.7 & 54.7 \\
\hline September & 13.5 & 14.5 & 14.9 & 13.9 & 42.3 & 47.1 & 13.6 & 80.1 \\
\hline $\begin{array}{c}\text { April - } \\
\text { September }\end{array}$ & 15.0 & 15.2 & 15.8 & 14.6 & 335.4 & 295.1 & 200.9 & 335.4 \\
\hline
\end{tabular}

\section{RESULTS AND DISCUSSION}

\section{The content and uptake of $\mathrm{Zn}$}

The research indicates that the varietal features were the dominant factor that significantly affected the zinc content in potato tubers (Table 3 ). The variety that contained the most of this ingredient was Honorata, followed by cv. Jelly and Tajfun. The Jelly variety was characterized by the highest average uptake of the element (163.7 $\mathrm{g} \cdot \mathrm{ha}^{-1}$ ) with the yield of tubers (Table 4). Other authors came to similar conclusions [Zarzecka 2003, Wierzbowska et al. 2015], showing a significant variation between these varieties in the content of zinc in potato tubers.

In the presented research, the applied biostimulators influenced the content and uptake of zinc with the tuber yield compared to the control variant. The highest content and the ability to take the element up were reported on the objects where BrunatneBio Złoto ${ }^{\circledR}$ biostimulator was used (Tables 3, 4). After the application of BrunatneBio Złoto ${ }^{\circledR}$ biostimulator, the average zinc content amounted to $13.5 \mathrm{mg} \cdot \mathrm{kg}^{-1}$ s.m. in tubers, and its uptake from tubers -150.4 $\mathrm{g} \cdot \mathrm{ha}^{-1} \mathrm{Zn}$. Similar results were obtained by Rudzińska-Mękal and Mikos-Bielak [2000]. In the studies of Wierzbowska et al. [2015], potato tubers on which Kelpak biostimulator was applied were characterized by the highest content of zinc ( $16.08 \mathrm{mg} \cdot \mathrm{kg}^{-1} \mathrm{~d}$.m.). In turn, according to Zarzecka [2003] and Zarzecka and Gugała [2009], the use of herbicides decreased the content of zinc in the analysed tubers.

A significant influence of the weather conditions on the content and uptake of micronutrients with the yield of tubers was presented by Medyńska et al. [2009], Gugała and Zarzecka [2011], Zarzecka et al. [2016]. In the analysed vegetation seasons, significant differences in the content and uptake of zinc with the tuber yield were reported (Tables 2, 3). In 2017, the highest average concentration $\left(13.4 \mathrm{mg} \cdot \mathrm{kg}^{-1} \mathrm{~s} . \mathrm{m}\right.$.) as well as the uptake of the element $\left(161.4 \mathrm{~g} \cdot \mathrm{ha}^{-1}\right)$ were obtained. It was the year with the highest amount of rainfall and the lowest average air temperature.

According to Kabat-Pendias, A.B. Mukherjee [2007] and Wierzbicka [2012], the acceptable content of zinc in potatoes is: $50-100 \mathrm{mg} \cdot \mathrm{kg}^{-1} \mathrm{~s} . \mathrm{m}$. The content of zinc in potato tubers on which biostimulators were applied was on average $13.4 \mathrm{mg} \cdot \mathrm{kg}^{-1} \mathrm{DM}$, and according to the recommendations of the Academy of Food and Nutrition Sciences in the USA, the daily standard of this element is $8 \mathrm{mg}$ [Wierzbicka, 2012]. Consumption of 100 grams of potatoes covers approx. $2-3 \%$ of the daily required zinc intake.

Table 3. Content of zinc $(\mathrm{Zn})$ in potato tubers ( $\mathrm{mg} \mathrm{kg}^{-1}$ dry matter)

\begin{tabular}{|l|c|c|c|c|c|c|c|}
\hline \multirow{2}{*}{ Variants (II) } & \multicolumn{3}{|c|}{ Cultivars (I) } & \multicolumn{3}{c|}{ Years (III) } & \multirow{2}{*}{ Mean } \\
\cline { 2 - 7 } & Honorata & Jelly & Tajfun & 2015 & 2016 & 2017 & \\
\hline 1. Control variant & 13.46 & 13.25 & 13.22 & 13.25 & 13.28 & 13.41 & $13.31 \mathrm{c}$ \\
2. Kelpak SL & 13.49 & 13.26 & 13.26 & 13.31 & 13.29 & 13.42 & $13.34 \mathrm{c}$ \\
3. Tytanit & 13.55 & 13.36 & 13.28 & 13.29 & 13.38 & 13.47 & $13.38 \mathrm{a}$ \\
4. Green OK & 13.53 & 13.41 & 13.28 & 13.34 & 13.41 & 13.48 & $13.4 \mathrm{ab}$ \\
5. BrunatneBio Złoto & 13.61 & 13.48 & 13.37 & 13.37 & 13.43 & 13.67 & $13.5 \mathrm{ab}$ \\
\hline \multicolumn{1}{|c|}{ Mean } & $13.53 \mathrm{c}$ & $13.35 \mathrm{a}$ & $13.28 \mathrm{~b}$ & $13.32 \mathrm{c}$ & $13.3 \mathrm{~b}$ & $13.4 \mathrm{a}$ & $13.39 \mathrm{a}$ \\
\hline
\end{tabular}

The means marked by the same letter do not differ significantly. 
Table 4. Uptake of zinc ( $\mathrm{Zn})$ with the yield of potato tubers $\left(\mathrm{g} \mathrm{ha}^{-1}\right)$

\begin{tabular}{|ll|c|c|c|c|c|c|c|}
\hline \multirow{2}{*}{ Variants (II) } & \multicolumn{3}{c|}{ Cultivars (I) } & \multicolumn{3}{c|}{ Years (III) } & \multirow{2}{*}{ Mean } \\
\cline { 3 - 8 }$n$ & Honorata & Jelly & Tajfun & 2015 & 2016 & 2017 & \\
\hline 1. & Control variant & 126.5 & 157.7 & 130.9 & 125.9 & 138.1 & 154.2 & $138.9 \mathrm{c}$ \\
2. & Kelpak SL & 132.2 & 161.8 & 136.6 & 133.1 & 140.9 & 157.0 & $143.6 \mathrm{c}$ \\
3. & Tytanit & 139,6 & 165.7 & 140.8 & 138.2 & 143.2 & 164.3 & $148.6 \mathrm{a}$ \\
4. & Green OK & 140.7 & 167.6 & 143.4 & 140.4 & 146.2 & 164.5 & $150.5 \mathrm{ab}$ \\
5. & BrunatneBio Złoto & 136.1 & 165.8 & 144.4 & 139.0 & 150.4 & 166.8 & $150.4 \mathrm{ab}$ \\
\hline \multicolumn{2}{|c|}{ Mean } & $135.0 \mathrm{c}$ & $163.7 \mathrm{a}$ & $139.20 \mathrm{~b}$ & $135.3 \mathrm{c}$ & $143.8 \mathrm{~b}$ & $161.4 \mathrm{a}$ & $146.4 \mathrm{a}$ \\
\hline
\end{tabular}

The mean marked by the same letter do not differ significantly.

\section{The content and uptake of $\mathrm{Cu}$}

The research conducted showed that the varieties cultivated in the experiment differed in terms of copper content in potato tubers. The average copper content in potato tubers ranged from 3.2 to $3.7 \mathrm{mg} \cdot \mathrm{kg}^{-1} \mathrm{~d}$.m. and depended significantly on the varietal factor. The highest average elemental content was reported in the Honorata variety, and the smallest in the Tajfun variety (Table 5). The highest capacity for uptaking copper $\left(41.2 \mathrm{~g} \cdot \mathrm{ha}^{-1}\right)$ with the yield of tubers was displayed by the Jelly variety, and the smallest $\left(33.8 \mathrm{~g} \cdot \mathrm{ha}^{-1}\right)$ by the Honorata variety (Table 6). The differences between varieties in the copper content were demonstrated by Browszys et al. [2009], Zarzecka and Gugała [2009], Gugała and Zarzecka [2011], Wierzbowska et al. [2015], Zarzecka et al. [2016].

The biostimulants used in the experiment significantly increased the amount of copper in potatoes. The highest content and the ability to take the element up were reported on the objects where BrunatneBio Złoto ${ }^{\circledR}$ biostimulator was used (Tables 5, 6). The interactions found between the experience factors and the years translate into the individual response of varieties to the applied preparations and weather conditions in the years of research.

Similar results were obtained by Wierzbowska et al. [2015]. The authors found a significant increase in the concentration of copper in tubers, which was caused by the use of Kelpak biostimulator. These results are in line with the research carried out by Westermann [2005], Grzyś [2012], which show that the use of biostimulators increased the copper uptake with potato tuber yield.

Climatic conditions in the study years had a significant effect on the concentration and uptake of copper with the yield of potato tubers (Tables $5,6)$. The tubers characterized by the highest content and uptake of the element were harvested in 2017, and that was a year of excessive rainfall. In turn, the lowest concentration and the lowest copper uptake were reported in 2015. It was a year with the smallest average rainfall and the highest air temperature. According to Kabat-Pendias and A.B. Mukherjee [2007] and Wierzbicka [2012], the acceptable content of copper in potatoes is: 20 $\mathrm{mg} \cdot \mathrm{kg}^{-1} \mathrm{~s} . \mathrm{m}$. The content of copper in potato tubers on which biostimulators were applied was on average $3.45 \mathrm{mg} \cdot \mathrm{kg}^{-1} \mathrm{DM}$, and according to the recommendations of the Academy of Food and Nutrition Sciences in the USA, the daily standard of this element is 900 micro/g [Wierzbicka, 2012]. Consumption of 100 grams of potatoes covers approx. $11 \%$ of the daily required copper intake.

\section{CONCLUSIONS}

1. The variants with biostimulators used in the experiment had a significant impact on increasing the content of zinc and copper and the uptake of these microelements with the yield of potato tubers in relation to the control variant.

Table 5. Content of copper $(\mathrm{Cu})$ in potato tubers $\left(\mathrm{mg} \mathrm{kg}^{-1}\right.$ dry matter)

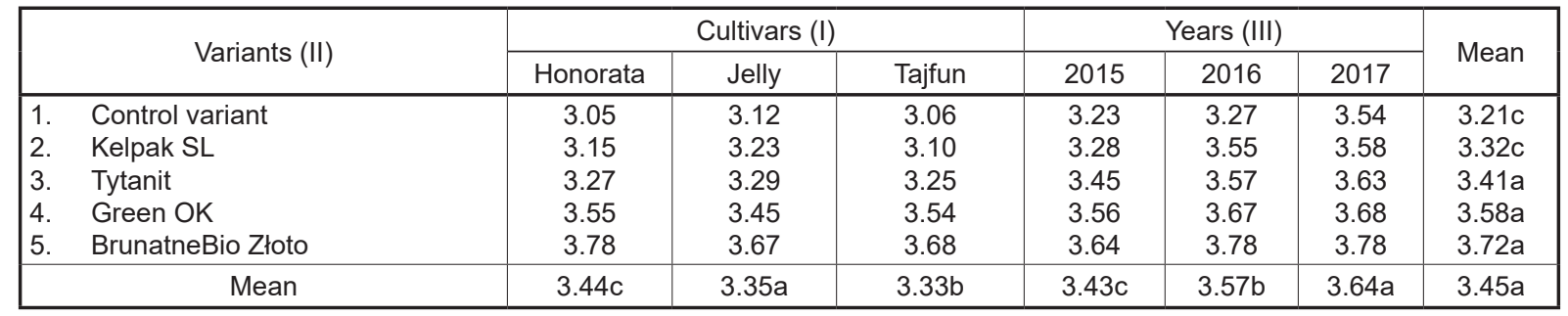

The means marked by the same letter do not differ significantly. 
Table 6. Uptake of copper $(\mathrm{Cu})$ in potato tubers $\left(\mathrm{g} \mathrm{kg}^{-1}\right.$ dry matter)

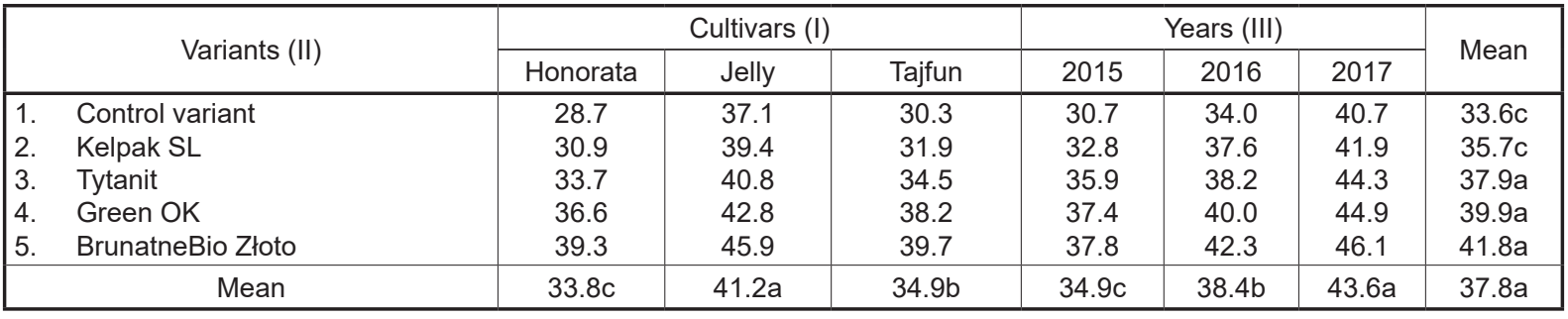

The means marked by the same letter do not differ significantly.

2. The varietal factor influenced the concentration and uptake of microelements with the tuber yield. The highest average content of zinc and copper was reported in the Honorata variety. The Jelly variety was distinguished by the highest ability to take up microelements with tuber yield.

3. The concentration and uptake of zinc and copper were influenced by climatic conditions. The highest content and uptake of zinc and copper was reported in the tubers collected in 2017, and the year was characterized by the lowest average air temperature and excessive rainfall.

\section{REFERENCES}

1. Alamar M.C., Tosetti R., Landahl S., Bermejo A., Terry L.A. 2017. Assuring Potato Tuber Quality during Storage: A Future Perspective. Frontiers in Plant Science, 28, 8-20.

2. Browszys T., Wierzbowska J., Bowszys J. 2009. Content and removal of $\mathrm{Cu}$ and $\mathrm{Zn}$ with harvested crops grown on soil fertilized with composted municipal sewage sludge. Journal of Elementology, 14(1), 23-32.

3. Camire M.E., Kubow S., Donnelly D.J. 2009. Potatoes and human health. Crit. Rev. Food Science \& Nutrition 49(10), 823-840.

4. Czeczko, R., Mikos-Bielak, M. 2004. Effects of Asahi bio-stimulator application in the cultivation of different vegetable species. Annales UMCS sec. E, Agricultura, 59 (3), 1073-1079.

5. Farouk S. 2015. Imroving growth and productivity of potato (Solanum tuberosum L.) by some biostimulants and lithovit with or without boron. Journal of Plant Production Mansoura University, 6(12), 2187- 2206.

6. Gugała M., Zarzecka K. 2011. Copper and zinc contents in edible potato tubers influenced by an application of new generation insecticides. Fresenius Environmental Bulletin, 20(7a), 1793-1796.

7. Grzyś E. 2012. The effect of some biologically active substances on maize grown under stress conditions. Monografie CXLV. Wyd. UP Wrocław 101.
8. Kabata-Pendias, A. and A. B. Mukherjee. 2007. Trace Elements from Soil to Human, SpringerVerlag Berlin Heidelberg, New York.

9. Kołodziejczyk M. 2016. Effect of nitrogen fertilization and microbial preparations on quality and storage lossesin potato cultivation. Acta Agrophysica, $23(1), 67-78$.

10. Klikocka H. 2001. Impact of applying different cultivation methods and cultivating potatoes on the content of macroelements in their tubers. Biuletyn IHAR, 217, 197-203. (in Polish).

11. Leszczyński W. 2012. Nutrition value of potato and potato products - Literature overview. Biuletyn IHAR, 266, 5-20. (in Polish).

12. Maciejewski T., Michalski T., Bartos-Spychała M., Ceślicki W., Nowacki W. 2008. Effect of the application of biostimulator Asahi SL on the yield of potato tubers and their quality. In: Biostimulators in modern agriculture. Part: Solanaceous crops. (Ed.) Dąbrowski Z. T., Wyd. Wieś Jutra, Warszawa, 52-60.

13. Medyńska A., Kabała C., Chodak T., Jezierski P. 2009. Concentration of copper, zinc lead and cadmium in plants culitivated in the surroundings of Żelazny Most copper ore tailings impoundment.

14. Mahamud M.A., Chowdhury M.A.H., Rahim M.A., Mohiuddin K.M. 2015. Mineral nutrient contents of some potato accessions of USA and Bangladesh. J. Bangladesh Agril. Univ. 13(2): 207-214.

15. Pszczółkowski P., Sawicka B., 2018. The effect of application of biopreparations and fungicides on the yield and selected parameters of seed value of seed potatoes. Acta Agrophysica, 25(2), 239-255.

16. Rudzińska-Mękal B., Mikos-Bielak M. 2000. The influence of growth regulators on the content of microelements in potato tubers. Zeszyty Problemowe Postępów Nauk Rolniczych, 471, 505-512.

17. Trawczyński C. 2014. The effect of amino acid biostimulators - tecamin - on potato yield and quality. Ziemniak Polski, 3, 29-34. (in Polish).

18. Trętowski, J., Wójcik, R. (1988). Methodology of agricultural experience. Wdawnictwo WSRP, Siedlce, 1-500. (in Polish).

19. Szewczuk C. 2009. The effect of foliar feeding on the yield of potato tubers. Annales UMCS, sec. E, Agricultura, 64 (1), 7-12. (in Polisch).

20. Van Oosten M.J., Pepe O., De Pascale S., Siletti 
S., Maggio A. 2017. The role of biostimulants and bioeffectors as alleviators of abiotic stress in crop plants. Chemical and Biological Technologies in Agriculture, 4, 1-12.

21. Wierzbicka, A. 2012. Mineral content of potato tubers grown in the organic system their nutritional value and interaction. Journal of Research and Applications in Agricultural Engineering, 57(4), 188-192.

22. Wierzbowska J., Cwalina-Ambroziak B., Bowszyc T., Głosek-Sobieraj M., Mackiweicz-Walec E. 2015. Content of microelements in tubers of potato treated with biostimulators. Polish Journal of Natural Sciences, 30(3), 225-234.

23. Wierzbowska J., Cwalina-Ambroziak B., GłosekSobieraj M., Sienkiewicz S. 2016. Content of minerals in tubers of potato plants treated with bioregulators. Rom. Agric. Res., 33: 291-298.

24. Westermann D. 2005. Nutritional Requirements of Potatoes. American Journal of Potato Research, 82, 301-307.
25. Zarzecka K. 2003. Effect of different cultivation methods on copper and zinc contents in potato tubers. Journal of Elementology, 8(1), 41-48.

26. Zarzecka K, Gugała M. 2009. The effect of cultivation operations on the copper and zinc content and accumulation in potato tubers. Fresenius Environmental Bulletin, 18(7), 1054-1058.

27. Zarzecka K., Gugała M. 2018. The effect of herbicides and biostimulants on sugars content in potato tubers. Plant Soil and Environment, 64(2), 82-87.

28. Zarzecka K., Gugała M., Baranowska A., Dołęga H., Sikorska A. 2016. Concentrations of copper, zinc and manganese in potato tuberss under the influence of herbicides. Journal of Elementology, 21(1), 259-267.

29. Żołnowski A.C. 2013. Studies on variability in yield and quality of edible potato (Solanum tuberosum L.) under conditions of differentiated mineral fertilization. UWM Olsztyn (Dissertations and monographs), 191: 1-259. 